Article

\title{
Study on the Extraction Technology of Candida antarctica Lipase B by Foam Separation
}

\author{
Wenyao Shao*, Ying Lin and Yinghua Lu*(D) \\ Department of Chemical and Biochemical Engineering, College of Chemistry and Chemical Engineering, \\ Xiamen University, Xiamen 361005, China; 20620191151427@stu.xmu.edu.cn \\ * Correspondence: wyshao@xmu.edu.cn (W.S.); ylu@xmu.edu.cn (Y.L.); Tel./Fax: +86-592-218-8848 (W.S.)
}

check for updates

Citation: Shao, W.; Lin, Y.; Lu, Y. Study on the Extraction Technology of Candida antarctica Lipase B by Foam Separation. Processes 2021, 9, 14. https:/ / dx.doi.org/10.3390/pr9010014

Received: 16 November 2020 Accepted: 18 December 2020 Published: 23 December 2020

Publisher's Note: MDPI stays neutral with regard to jurisdictional claims in published maps and institutional affiliations.

Copyright: () 2020 by the authors. Licensee MDPI, Basel, Switzerland. This article is an open access article distributed under the terms and conditions of the Creative Commons Attribution (CC BY) license (https: / creativecommons.org/ licenses/by/4.0/).
Abstract: Candida antarctica Lipase B (CALB) has a wide range of applications in many fields. In this study, Pichia pastoris was used to express CALB for fermentation tank culture. Sodium dodecyl sulfate (SDS) was used as a surfactant, and foam separation technology was used to explore the best experimental conditions for the harvest of CALB. The results showed that the optimal technological conditions for the foam separation and recovery of CALB were as follows: liquid volume was $150 \mathrm{~mL}$, separating gas velocity was $600 \mathrm{~mL} / \mathrm{min}$, $\mathrm{pH}$ value was 7, and surfactant SDS concentration was $0.5 \mathrm{mg} / \mathrm{mL}$. Under these conditions, the enrichment ratio of CALB was 0.95 , and recovery rate $\mathrm{R}$ was $80.32 \%$, respectively, indicating that the foam separation technology is feasible to extract lipase B.

Keywords: foam separation; fermentation; lipase; surfactant; enrichment ratio; recovery rate

\section{Introduction}

In recent years, increasing attention has been paid to the production and application of CALB. CALB is a triacylglycerol hydrolysis enzyme [1] which can be utilized to catalyze the decomposition of tributyrate glycerol into fatty acids and glycerol [2]. CALB catalysis has a good stability and selectivity as well as mild reaction conditions, and its application covers many fields including food industry [3], household chemical industry [4], organic synthesis [5], biomedicine [6] and so on. The traditional isolation and purification methods of CALB contain hydrophobic chromatography [7], dual water phase extraction [8], membrane separation [9], and immunopurification techniques. Foam separation technology is a new separation technology developing rapidly in the recent 20 years [10]. According to the principle of surface adsorption, it makes a surface-active substance in the solution gather at the gas-liquid interface (bubble surface), and then the bubbles transfer to the foam layer when they reach the top of the solution [11]. By separating the foam layer and the liquid phase, it can purify the liquid phase and concentrate the surface-active substances (in the foam layer). The application field of foam separation technology is constantly expanding, mainly being used in wastewater treatment, food, biology, medicine, chemical industry, etc. $[12,13]$.

CALB contains hydrophilic and hydrophobic groups [14]. Due to its hydrophobicity enhanced by external conditions or its own characteristic, CALB can be efficiently collected by foam separation technology. The mechanism of foam separation technology is illustrated in Figure 1. The factors affecting foam separation include the $\mathrm{pH}$ value of the solution, the separated gas velocity, the liquid volume, the initial enzyme concentration, the type and concentration of surfactants, and the collection time. The $\mathrm{pH}$ value mainly affects the chargeability of the protein. The protein molecule is uncharged at the isoelectric point, resulting in the lowest liquid surface tension and the strongest hydrophobicity [15]. Therefore, the solution is easier to form stable foam for adsorption. When the gas velocity is low, CALB has more time to be adsorbed to the gas-liquid interface. But if the time is too long, the biological activity of CALB will be greatly affected [16]. Liquid volume affects the stay time of bubbles in the liquid phase [17]. When the initial enzyme concentration 
is low, the amount of CALB adsorbed by the surfactant has a linear relationship with the concentration of CALB. When the concentration of CALB reaches the critical micelle concentration, the adsorption capacity of the bubbles reaches saturation [18]. Different types of surfactants have different adsorption properties. Surfactants of different concentrations mainly cause differences in the ratio of the height of the foam layer to the height of the liquid layer [19]. Increasing the collection time can make the bubbles and CALB contact more fully, which can increase the recovery rate of CALB enzyme activity, but it will cause the enrichment ratio of the enzyme concentration to decrease [20]. In this study, CALB expressed by Pichia pastoris was harvested by foam separation technology. Firstly, the Pichia pastoris GS115-pPIC9k-sy CALB was used for shaking flask culture; single factor experiment of foam separation was carried out on the culture supernatant of the shake flask to determine the optimal conditions for the harvest of lipase in the shake flask fermentation broth. Then, Pichia pastoris was cultured in a fermenter. According to the optimal conditions determined in the previous step, an orthogonal test was performed on the supernatant obtained from the fermentor to explore the optimal conditions for foam separation and harvesting CALB.

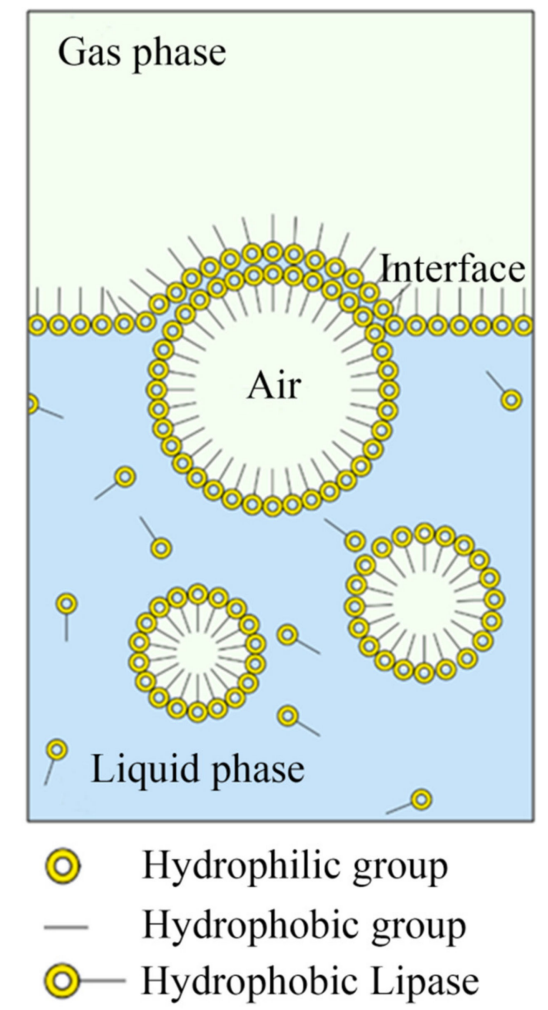

Figure 1. Adsorption of lipase B on the surface of bubbles.

\section{Materials and Methods}

\subsection{Main Reagents and Instruments}

Main reagents: Soapberry extract (SE) (40\% active ingredients), Fujian Sanqingyuan Biological Products Co., Ltd. (Ningde, Fujian, China); Cetyl trimethylammonium bromide (CTAB) (99.0\%), Sinopharm Chemical Reagent Co., Ltd. (Shanghai, China); Sodium dodecyl sulfate (SDS) (86.0\%), Sinopharm Chemical Reagent Co., Ltd.; Coomassie Brilliant Blue g520 (CP), Sinopharm Chemical Reagent Co., Ltd.; Tributyrin(CP), Tokyo Chemical Industry (Tokyo, Japan); Hydrochloric acid; Sodium hydroxide; Potassium dihydrogen phosphate; Dipotassium phosphate; Phenolphthalein.

Instruments: AB104N electronic balance (Sartorius); Lzb-3wb rotameter (Changzhou Shuanghuan Thermal Instrument Co., Ltd., Changzhou, China); SKY200B constant temperature shaker (SuKun Industrial Co., Ltd., Shanghai, China); HAMILTON fermenter 
(INFORS Biotechnology Co., Ltd., Bottmingen, Switzerland); 5810R centrifuge (Eppendorf Co., Ltd., Hamburg, Germany); Microplate reader (Molecular Devices Co., Ltd., California, USA); Foam separating device.

\subsection{Experimental Methods}

\subsubsection{Determination of CALB Concentration}

Using modified Coomassie Brilliant Blue spectrophotometric colorimetry [21], within a certain range of CALB concentration (100 1000 mg. $\left.\mathrm{L}^{-1}\right)$, the combination of CALB and Coomassie Brilliant Blue conforms to Lambert-Beer law. When Coomassie Brilliant Blue is combined with CALB, its color will change from yellow to blue. By measuring the OD value at $595 \mathrm{~nm}$, the amount of the binding protein could be calculated. $20 \mu \mathrm{L}$ of sample was mixed with $200 \mu \mathrm{L}$ of G250, with the fresh medium as a blank control, and the absorbance of the sample at $595 \mathrm{~nm}$ was measured with a microplate reader. The sample was measured three times and averaged. Protein concentration was calculated in the sample according to the standard curve. The sample was measured three times and averaged.

\subsubsection{Determination of CALB Activity}

Referring to the method of Pfeffer et al. [22], the CALB sample was added to tributyrin in phosphate buffer and shaken to emulsify, then reacted for $10 \mathrm{~min}$ in a constant temperature shaker at $30{ }^{\circ} \mathrm{C}$ and $200 \mathrm{rpm}$. Using phenolphthalein as an indicator, we titrated with $\mathrm{NaOH}$ standard solution and recorded the consumed volume $\mathrm{V}$ of $\mathrm{NaOH}$ standard solution. One CALB enzyme activity unit $(\mathrm{U})$ is defined as the amount of enzyme required to catalyze the hydrolysis of tributyrin to $1 \mu \mathrm{mol}$ butyrate per minute at $35^{\circ} \mathrm{C}$ and $\mathrm{pH}=6.8$. The sample was measured three times and averaged. The calculation formula of enzyme activity was as follows:

$$
A=\frac{V_{0} \times C_{0}}{V_{c} \times t}
$$

where $A$ is enzyme activity $\left(\mathrm{U} \cdot \mathrm{mL}^{-1}\right), V_{0}$ is the volume of standard $\mathrm{NaOH}$ consumed $(\mathrm{mL})$, $C_{0}$ is the molar concentration of $\mathrm{NaOH}$ standard solution $\left(100 \mathrm{mmol} \cdot \mathrm{L}^{-1}\right), V_{c}$ is sample volume $(1 \mathrm{~mL})$, and $t$ is reaction time $(10 \mathrm{~min})$.

\subsubsection{Foam Separation Process}

Figure 2 is a schematic diagram of the self-built foam separation device. All experiments were performed at room temperature. We checked the air-tightness of the device and whether the connection was normal. The required CALB sample solution was prepared by changing the surfactant concentration and adjusting the $\mathrm{pH}$. The CALB culture with surfactant solution was fed into a foam separation column with a desired height at the beginning of each experiment, and the foam was generated by bubbling the air into the column through the gas distributor. The lipase concentration and activity in the sample were measured and recorded when the foam solution was completely defoamed. We then calculated and analyzed the enzyme concentration enrichment ratio E and enzyme activity recovery rate $\mathrm{R}$. 


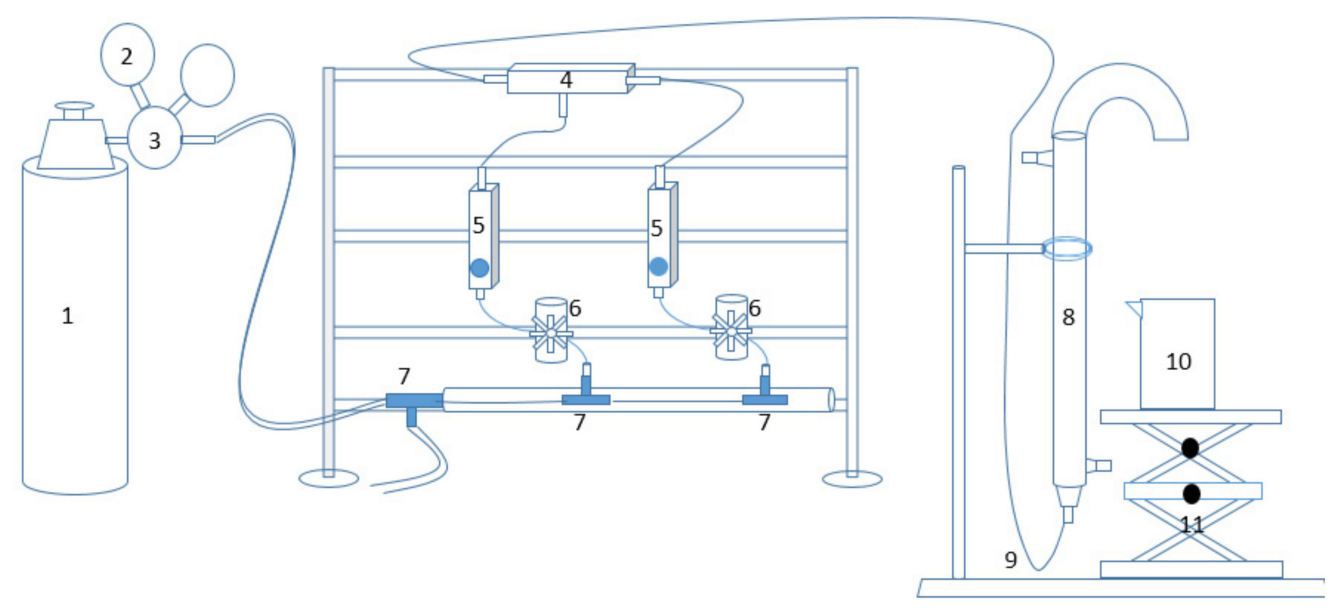

Figure 2. Schematic diagram of the foam separation device. 1, compressed air cylinder; 2 , gas cylinder pressure gauge; 3 , cylinder reduction valve; 4 , gas mixer; 5 , rotameter; 6 , branch control valve; 7 , main control valve; 8 , foam separation column; 9, iron stand; 10, sample collection beaker; 11, lift.

\subsubsection{Evaluation of Foam Separation Effect}

Evaluation of the foam separation effects is defined by enrichment ratio (E), enzyme recovery $(\mathrm{R})$ as follows:

$$
\begin{gathered}
E=\frac{C_{1}}{C_{0}} \times 100 \% \\
R=\frac{A_{1} V_{1}}{A_{0} V_{0}} \times 100 \%
\end{gathered}
$$

where $C_{1}$ is the lipase concentration of collected foam liquid $(\mathrm{mg} / \mathrm{mL}), C_{0}$ is the lipase concentration of initial solution $(\mathrm{mg} / \mathrm{mL}), V_{1}$ is the volume of foam liquid $(\mathrm{mL}), V_{0}$ is the volume of initial solution $(\mathrm{mL}), A_{1}$ is the enzyme activity of foam liquid $(\mathrm{U} / \mathrm{mL})$, and $A_{0}$ is the enzyme activity of initial solution $(\mathrm{U} / \mathrm{mL})$.

\subsubsection{Single-Factor Experiment of Lipase in Fermentation Broth from Shaker Flask}

The fermentation broth cultured in the shake flask was centrifuged at $20{ }^{\circ} \mathrm{C}$ and $6000 \mathrm{rpm}$ for $5 \mathrm{~min}$, and the supernatant was collected as the initial enzyme solution for the foam separation experiment. The enzyme activity and the lipase concentration of the initial solution were measured and recorded. Then we proceeded to foam separation and recorded the data before calculating the enrichment ratio $\mathrm{E}$ and enzyme activity recovery rate $R$. The best process conditions were identified, to proceed to the next experiment.

\subsubsection{Orthogonal Experimental Design of Lipase in Fermentation Broth from Fermenter}

The fermentation broth in the fermenter was centrifuged at $20^{\circ} \mathrm{C}, 6000 \mathrm{rpm}$ for $5 \mathrm{~min}$, and the supernatant was collected as the initial enzyme solution of the foam separation experiment. The enzyme activity and the lipase concentration of the initial solution were measured and recorded. According to the conditions obtained from Section 2.2.5, the orthogonal experiment was carried out and the enrichment ratio $E$ and enzyme activity recovery rate $\mathrm{R}$ calculated and analyzed to obtain the best process conditions.

\section{Results and Discussion}

\subsection{Single-Factor Investigation of the Recovery Effect of Lipase in Shake Flask \\ 3.1.1. The Effect of Separated Gas Velocity}

After centrifuging the fermentation broth cultured in the shake flask, the supernatant was taken for the foam separation experiment. The separated gas velocity varied from 200 to $1000 \mathrm{~mL} / \mathrm{min}$, and the gradient was $200 \mathrm{~mL} / \mathrm{min}$ for five groups' experiments of foam separation. Regarding other experimental conditions: the $\mathrm{pH}$ value of the solution was 
6 , the lipase concentration of the initial solution was $0.15 \mathrm{mg} / \mathrm{mL}$, the enzyme activity of initial solution was $124 \mathrm{U} / \mathrm{min}$, the concentration of surfactant SDS was $0.2 \mathrm{mg} / \mathrm{mL}$, the liquid volume was $100 \mathrm{~mL}$, and the collection time was $15 \mathrm{~min}$. The results are shown in Figure 3.

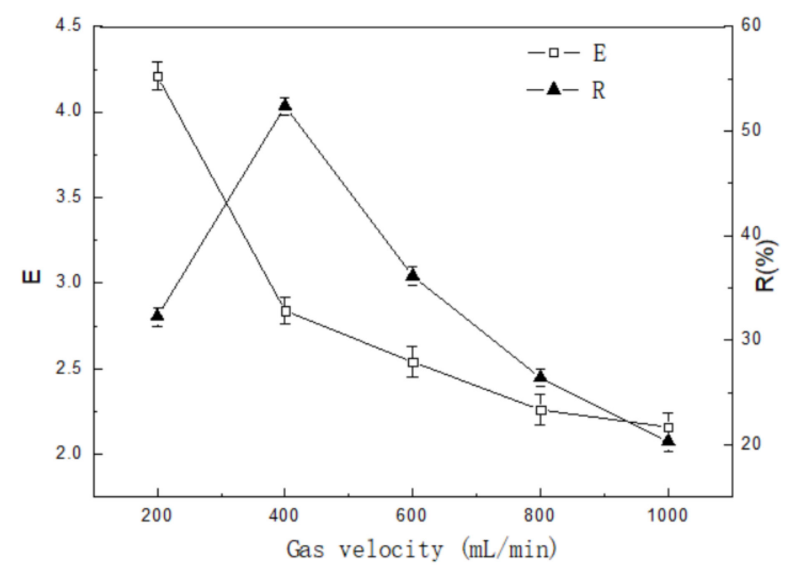

Figure 3. Effects of separated gas velocity on enrichment ratio and recovery.

According to the figure, the enzyme recovery rate $\mathrm{R}$ increased first and then decreased with the increase of separated gas velocity. When the gas velocity was $400 \mathrm{~mL} / \mathrm{min}$, the recovery rate of enzyme activity $\mathrm{R}$ was up to $52.36 \%$. However, the enrichment ratio E gradually decreased with the increase of liquid volume. When the gas velocity was $200 \mathrm{~mL} / \mathrm{min}$, the enrichment ratio $\mathrm{E}$ had a maximum value of 4.21 . Combined with the foam separation theory, it can be seen that when the gas velocity was small, the generated foam was sparse and unstable, and the lipase molecules were difficult to be fully adsorbed and discharged, resulting in a low recovery rate. When the gas velocity continued to increase, the gas rose faster and the foam generation at this time was large, and the contact time with the target molecules in the liquid phase was insufficient, thereby causing a decrease in the recovery rate. As the gas velocity increased, it was easier to bring out water molecules during the gas rise, resulting in a decrease in the enrichment ratio of the enzyme concentration. Therefore, combining E and R, the optimal condition of separated gas velocity was $400 \mathrm{~mL} / \mathrm{min}$.

\subsubsection{The Effect of Liquid Volume}

After centrifuging the fermentation broth cultured in the shake flask, the supernatant was taken for foam separation experiments. The liquid volume varies from 50 to $300 \mathrm{~mL}$, and the gradient was $50 \mathrm{~mL}$ for six groups' experiments of foam separation. Regarding other experimental conditions: the $\mathrm{pH}$ value of the solution was 6 , the lipase concentration of the initial solution was $0.15 \mathrm{mg} / \mathrm{mL}$, the enzyme activity of initial solution was $124 \mathrm{U} / \mathrm{min}$, the concentration of surfactant SDS was $0.2 \mathrm{mg} / \mathrm{mL}$, the gas velocity was $400 \mathrm{~mL} / \mathrm{min}$, and the collection time was $15 \mathrm{~min}$. The results are shown in Figure 4.

It can be seen from Figure 4 that the enzyme recovery rate $\mathrm{R}$ increased first and then decreased with the increase of liquid volume. When the liquid volume was $100 \mathrm{~mL}$, the enzyme recovery rate $\mathrm{R}$ reached up to $76.98 \%$. However, the enrichment ratio E gradually decreased with the increase of liquid volume. At the minimum volume of $50 \mathrm{~mL}$, the enrichment ratio $\mathrm{E}$ has a maximum value of 1.082. Combined with the foam separation theory [23], the liquid level in the separation column will be lower when the liquid volume is small. Therefore, the gas medium cannot stay in the tube for a long time and cannot fully contact with the liquid phase. As a result, the lipase molecules cannot be fully absorbed and attached to the bubbles, resulting in a reduced recovery effect. When the liquid volume exceeds a certain value, the gas will stay in the liquid phase for a longer time due to the higher liquid level in the column. Therefore, when the gas is in full contact with the liquid 
phase, it will take many water molecules along with the target material, thus reducing the enrichment ratio and recovery rate. With this consideration, the optimal condition of the liquid volume was $100 \mathrm{~mL}$.

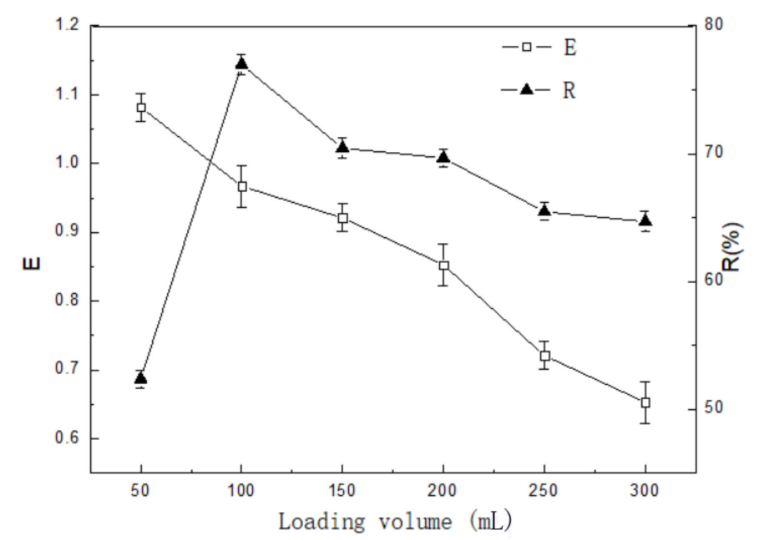

Figure 4. Effects of loading volume on enrichment ratio and recovery.

\subsubsection{The Effect of Solution $\mathrm{pH}$}

After centrifuging the fermentation broth cultured in the shake flask, the supernatant was taken for foam separation experiments. The $\mathrm{pH}$ value varied from 5 to 9 , and the gradient was 1 for five groups' experiments of foam separation. Regarding other experimental conditions: the lipase concentration of the initial solution was $0.15 \mathrm{mg} / \mathrm{mL}$, the enzyme activity of initial solution was $124 \mathrm{U} / \mathrm{min}$, the concentration of surfactant SDS was $0.4 \mathrm{mg} / \mathrm{mL}$, the gas velocity was $400 \mathrm{~mL} / \mathrm{min}$, liquid volume was $100 \mathrm{~mL}$, and collection time was $15 \mathrm{~min}$. The results are shown in Figure 5.

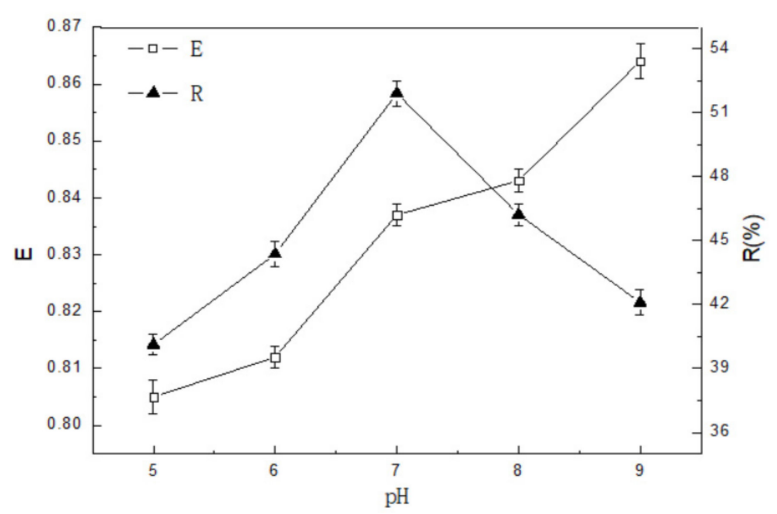

Figure 5. Effects of $\mathrm{pH}$ on enrichment ratio and recovery.

As can be seen from Figure 5, with the increase of $\mathrm{pH}$ value, the solution changed from weak acidity to weak alkalinity, and the enzyme recovery rate $\mathrm{R}$ first increased and then decreased. When the $\mathrm{pH}$ value was 7 , the solution was neutral, and the enzyme recovery rate $\mathrm{R}$ could reach up to $51.98 \%$. However, the enrichment ratio $\mathrm{E}$ gradually increased with the increase of $\mathrm{pH}$ value. When the $\mathrm{pH}$ value was 9, the enrichment ratio $\mathrm{E}$ had a maximum value of 0.863 . Due to the characteristics of lipase itself, the stability was better when the $\mathrm{pH}$ is weakly alkaline. Generally, the optimal $\mathrm{pH}$ value for its action is 9. Therefore, at a $\mathrm{pH}$ value of 9 , lipase molecules can be absorbed by bubbles to the maximum extent, thus having the maximum enrichment ratio. When the $\mathrm{pH}$ value is 7 , since the force of the water molecules is the smallest at this time, the water's molecular weight entrained during the process of foam separation is the least, thus having the maximum recovery rate. Considering the enzyme concentration enrichment ratio $\mathrm{E}$ and enzyme activity recovery rate $\mathrm{R}$. , the optimal condition for $\mathrm{pH}$ value of the solution was 7 . 


\subsubsection{The Effect of Surfactant Concentration}

After centrifuging the fermentation broth cultured in the shake flask, the supernatant was taken for foam separation experiments. The concentration of surfactant SDS varies from 0.1 to $0.5 \mathrm{mg} / \mathrm{mL}$, and the gradient was $0.1 \mathrm{mg} / \mathrm{mL}$ for five groups' experiments of foam separation. Regarding other experimental conditions: the $\mathrm{pH}$ of the solution was 6, the lipase concentration of the initial solution was $0.15 \mathrm{mg} / \mathrm{mL}$, the enzyme activity of the initial solution was $124 \mathrm{U} / \mathrm{min}$, the liquid volume was $100 \mathrm{~mL}$, the gas velocity was $400 \mathrm{~mL} / \mathrm{min}$, and the collection time was $15 \mathrm{~min}$. The results are shown in Figure 6.

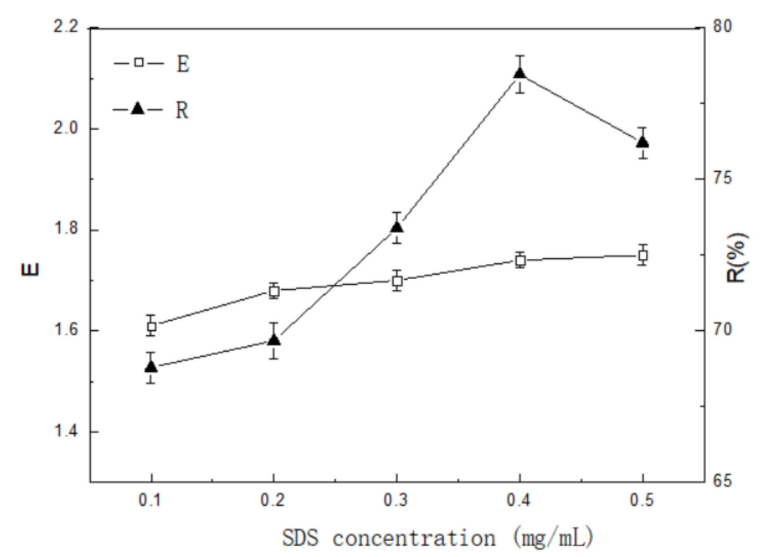

Figure 6. Effects of concentration of SDS on enrichment ratio and recovery.

According to the figure, the enzyme recovery rate $\mathrm{R}$ increased first and then decreased with the increase of surfactant concentration. When the surfactant concentration was $0.4 \mathrm{mg} / \mathrm{mL}$, the enzyme recovery rate $\mathrm{R}$ could reach up to $78.46 \%$. The enrichment ratio of $\mathrm{E}$ increased gradually with the increase of surfactant concentration. When the surfactant concentration was $0.5 \mathrm{mg} / \mathrm{mL}$, the enrichment ratio of $\mathrm{E}$ had a maximum value of 1.75 . Combined with the theory of foam separation, it can be seen that as the concentration of the surfactant increased, more bubbles were generated in the solution, so the adsorption capacity was stronger, resulting in an increase in the enrichment ratio. When the concentration of the surfactant exceeds a certain value, the surfactant itself will start the association reaction, thereby reducing the effective adsorption of the lipase molecule, resulting in a decrease in the recovery rate. With this consideration, the optimum condition of surfactant concentration was $0.4 \mathrm{mg} / \mathrm{mL}$.

Based on the above results, the optimal process conditions for lipase harvesting in the shaker fermentation broth are: $\mathrm{pH}$ value is 7 , the concentration of surfactant SDS is $0.4 \mathrm{mg} / \mathrm{mL}$, the liquid volume is $100 \mathrm{~mL}$, the separated gas velocity is $400 \mathrm{~mL} / \mathrm{min}$, and collection time is $15 \mathrm{~min}$. The next experiment was designed under the best condition.

\subsection{Orthogonal Experiment to Investigate the Effect of Lipase Harvesting in Fermenter}

The collection time was determined to be $15 \mathrm{~min}$ by the above single factor experiment. The separated gas velocity was $200 \sim 600 \mathrm{~mL} / \mathrm{min}$, the liquid volume was $50 \sim 150 \mathrm{~mL}$, the $\mathrm{pH}$ was $6 \sim 8$, and the concentration of surfactant SDS was $0.3 \sim 0.5 \mathrm{mg} / \mathrm{mL}$ as the variable range of each factor. Orthogonal test table $\left(\mathrm{L}_{9} 3^{4}\right)$ was designed based on the optimal process conditions obtained in Section 3.1, as shown in Table 1.

The experiment was carried out according to the design of Table 1, and the enrichment ratio $\mathrm{E}$ of enzyme concentration and recovery rate $\mathrm{R}$ of enzyme activity were used as evaluation indexes. The experimental scheme and data are shown in Table 2. 
Table 1. Factors and levels of the orthogonal experiment for lipase in the fermentation broth.

\begin{tabular}{ccccc}
\hline $\begin{array}{c}\text { Experiment } \\
\text { Number }\end{array}$ & $\begin{array}{c}\text { Separated Gas Velocity } \\
(\mathbf{m L} / \mathbf{m i n})\end{array}$ & Liquid Volume (mL) & pH & $\begin{array}{c}\text { Concentration of } \\
\text { Surfactant SDS (mg/mL) }\end{array}$ \\
\hline 1 & 200 & 50 & 6 & 0.3 \\
2 & 400 & 100 & 7 & 0.4 \\
3 & 600 & 150 & 8 & 0.5 \\
\hline
\end{tabular}

Table 2. Orthogonal experiment design and results analysis of lipase in the fermentation broth.

\begin{tabular}{|c|c|c|c|c|c|c|}
\hline Number & $\begin{array}{c}\text { Separation Gas } \\
\text { Velocity (mL/min) }\end{array}$ & $\begin{array}{l}\text { Liquid Volume } \\
(\mathrm{mL})\end{array}$ & $\mathrm{pH}$ & $\begin{array}{c}\text { Surfactant } \\
\text { Concentration } \\
(\mathrm{mg} / \mathrm{mL})\end{array}$ & $\begin{array}{l}\text { Enrichment } \\
\text { Ratio E }\end{array}$ & $\begin{array}{c}\text { Recovery } \\
\text { Rate R (\%) }\end{array}$ \\
\hline 1 & 200 & 50 & 6 & 0.3 & 0.88 & 25.13 \\
\hline 2 & 400 & 100 & 6 & 0.4 & 0.80 & 34.92 \\
\hline 3 & 600 & 150 & 6 & 0.5 & 0.85 & 73.36 \\
\hline 4 & 200 & 100 & 7 & 0.5 & 0.90 & 50.69 \\
\hline 5 & 400 & 150 & 7 & 0.3 & 0.93 & 39.05 \\
\hline 6 & 600 & 50 & 7 & 0.4 & 0.82 & 28.58 \\
\hline 7 & 200 & 150 & 8 & 0.4 & 0.72 & 51.16 \\
\hline 8 & 400 & 50 & 8 & 0.5 & 0.82 & 29.94 \\
\hline 9 & 600 & 100 & 8 & 0.3 & 0.88 & 68.76 \\
\hline $\bar{K}_{1}$ & 0.833 & 0.840 & 0.843 & 0.897 & & \\
\hline $\bar{K}_{2}$ & 0.850 & 0.860 & 0.883 & 0.780 & & \\
\hline $\bar{K}_{3}$ & 0.850 & 0.860 & 0.807 & 0.857 & & \\
\hline$R$ & 0.017 & 0.020 & 0.076 & 0.117 & & \\
\hline $\bar{K}_{1}^{\prime}$ & 42.327 & 27.883 & 44.470 & 44.313 & & \\
\hline $\bar{K}_{2}^{\prime}$ & 34.637 & 51.457 & 39.440 & 38.220 & & \\
\hline $\bar{K}_{3}^{\prime}$ & 56.900 & 54.523 & 49.953 & 51.330 & & \\
\hline$R^{\prime}$ & 22.263 & 26.640 & 10.513 & 13.110 & & \\
\hline
\end{tabular}

Statistical analysis of the data. $\bar{K}_{1}, \bar{K}_{2}$ and $\bar{K}_{3}$ represent the average value of the sum of $\mathrm{R}$ at the level 1, 2, and 3 of each single factor, and $R$ represents the range of $\bar{K}$ values. $\bar{K}_{1}^{\prime}, \bar{K}_{2}^{\prime}$ and $\bar{K}_{3}^{\prime}$ represent the average value of the sum of $\mathrm{R}$ corresponding to the level 1,2 , and 3 of each single factor, and $R^{\prime}$ represents the extreme difference of $\bar{K}^{\prime}$ values. The $\bar{K}$ value and $R$ value distribution of the enzyme enrichment ratio $E$ are respectively shown in Figures 7 and 8 , and the $\bar{K}^{\prime}$ value and $R^{\prime}$ value distribution of the enzyme recovery rate $R$ are respectively shown in Figures 9 and 10.

It can be seen from the above figure that the value of enzyme recovery rate $\mathrm{R}$ is taken as the main process condition selection indicator, and the optimal experimental process conditions were: liquid volume was $150 \mathrm{~mL}$, gas velocity was $600 \mathrm{~mL} / \mathrm{min}$, pH value was 7 , and concentration of surfactant SDS was $0.5 \mathrm{mg} / \mathrm{mL}$. Under these conditions, the enrichment ratio $\mathrm{E}$ and recovery rate $\mathrm{R}$ reached 0.95 and $80.32 \%$, respectively. The order of the degree of affecting the recovery rate $\mathrm{R}$ is: liquid volume $>$ separate gas velocity $>$ concentration of surfactant SDS $>\mathrm{pH}$. 


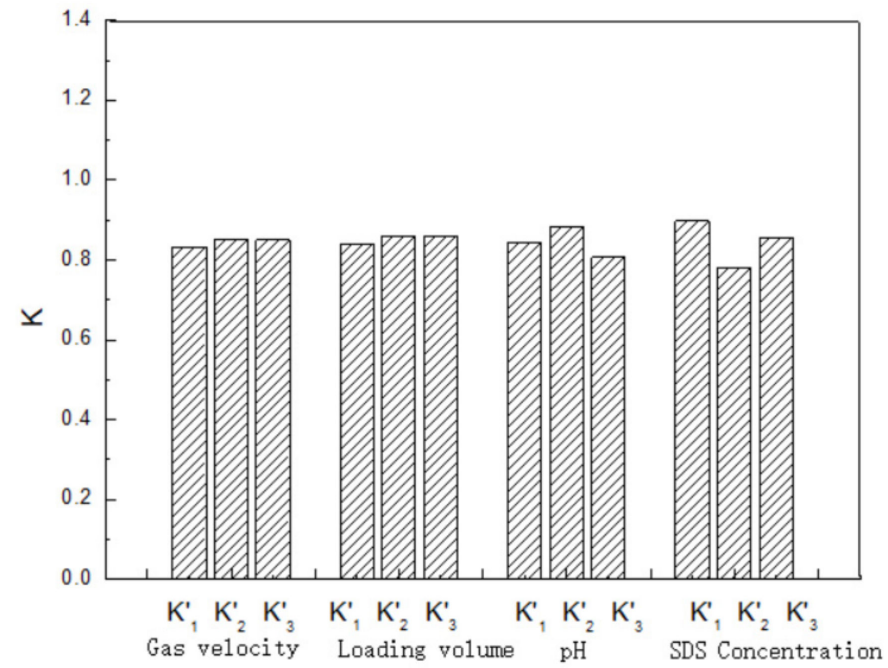

Figure 7. K value distribution of enrichment ratio E.

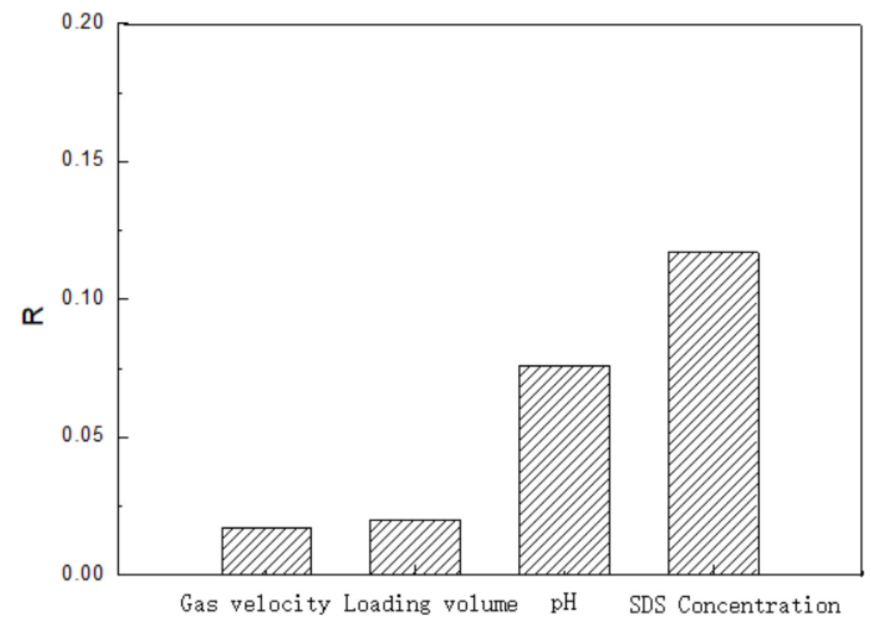

Figure 8. R value distribution of enrichment ratio E.

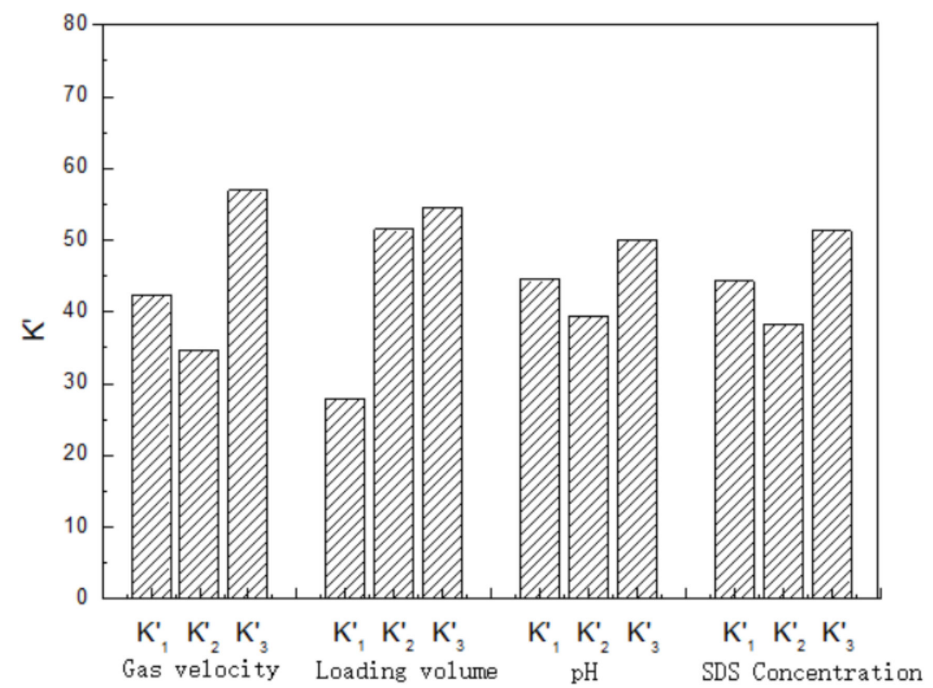

Figure 9. $K^{\prime}$ distribution of enzyme activity recovery $R$. 


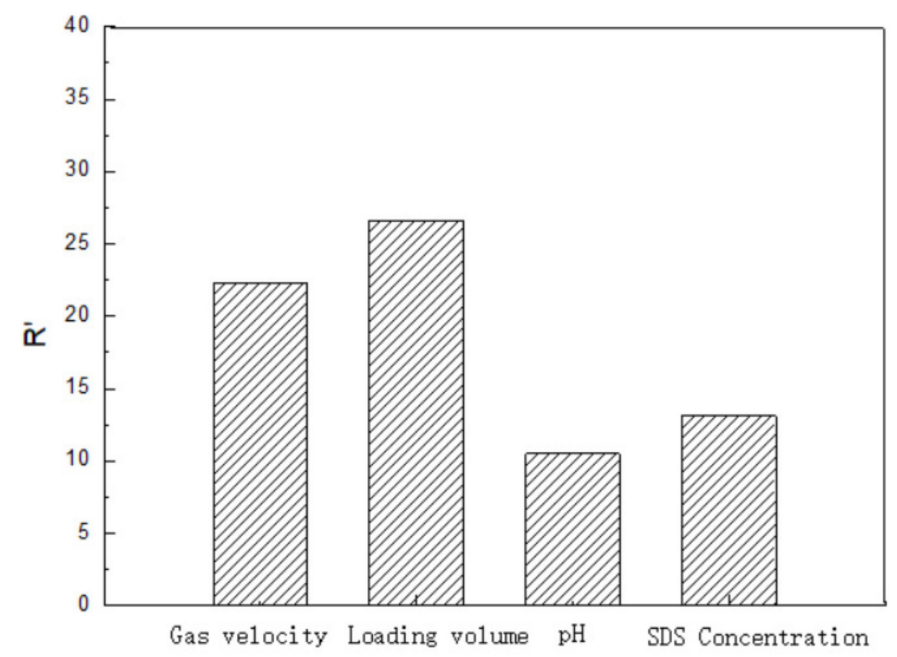

Figure 10. $R^{\prime}$ distribution of enzyme activity recovery $R$.

\section{Conclusions and Prospects}

In this paper, the CALB cultured in shake flasks was harvested first, and the optimal process conditions were as follows: $\mathrm{pH}$ value was 7 , the concentration of surfactant SDS was $0.4 \mathrm{mg} / \mathrm{mL}$, liquid volume was $100 \mathrm{~mL}$, separation gas velocity was $400 \mathrm{~mL} / \mathrm{min}$, and collection time was $15 \mathrm{~min}$. Then explore the best experimental process conditions for harvesting the CALB cultured in the fermenter, and the optimal process conditions were obtained as follows: liquid volume was $150 \mathrm{~mL}$, separating gas velocity was $600 \mathrm{~mL} / \mathrm{min}, \mathrm{pH}$ value was 7 , and concentration of surfactant SDS was $0.5 \mathrm{mg} / \mathrm{mL}$. Under these conditions, the enrichment ratio $\mathrm{E}$ and recovery rate $\mathrm{R}$ of $\mathrm{CALB}$ reached 0.95 and $80.32 \%$, respectively. In conclusion, it is feasible to collect lipase B by foam separation method. In this paper, factors influencing the extraction process include separation gas velocity, filling liquid volume, $\mathrm{pH}$ value, type, and concentration of surfactant. However, in the lipase solution produced by fermentation, there are many other impurities, such as glycerol, methanol, and other proteins, which may affect the foam separation and harvesting effect of lipase. Therefore, the influences of these factors can be considered in the future.

Author Contributions: W.S. provided theoretical support. Y.L. (Ying Lin) performed experimental operations. Y.L. (Yinghua Lu) provided theoretical support. All authors have read and agreed to the published version of the manuscript.

Funding: The authors gratefully acknowledge the financial support by Fundamental Research Funds for Technology Planning Project of Xiamen City, China (No. 3502Z20183016).

Conflicts of Interest: There are no conflict of interest.

\section{References}

1. Uppenberg, J.; Ohrner, N.; Norin, M.; Hult, K.; Kleywegt, G.J.; Patkar, S.; Waagen, V.; Anthonsen, T.; Jones, T.A. Crystallographic and molecular-modeling studies of lipase B from Candida antarctica reveal a stereospecificity pocket for secondary alcohols. Biochemistry 1995, 51, 16838-16851. [CrossRef] [PubMed]

2. Gandhi, N.N. Applications of lipase. J. Am. Oil. Chem. Soc. 1997, 74, 621-634. [CrossRef]

3. Priyanka, P.; Tan, Y.Q.; Kinsella, G.K.; Henehan, G.T.; Ryan, B.J. Solvent stable microbial lipases: Current understanding and biotechnological applications. Biotechnol. Lett. 2019, 41, 203-220. [CrossRef] [PubMed]

4. Vaisali, C.; Belur, P.D.; Regupathi, I. Lipase mediated synthesis of rutin fatty ester: Study of its process parameters and solvent polarity. Food Chem. 2017, 232, 278-285. [CrossRef] [PubMed]

5. Cen, Y.X.; Li, D.Y.; Xu, J. Highly Focused Library-Based Engineering of Candida antarctica Lipase B with (S)-Selectivity Towards sec-Alcohols. Adv. Synth. Catal. 2019, 361, 126-134. [CrossRef]

6. Rio, N.S.; Pinheiro, B.B.; Pinheiro, M.P.; Mendes Bezerra, R.; Santos, J.C.S.; Gonçalvesa, L.R. Biotechnological potential of lipases from Pseudomonas: Sources, properties and applications. Process Biochem. 2018, 75, 99-120. [CrossRef]

7. Bornscheucr, U.; Oscar-Werner, R.; Lausch, R.; Scheper, T.; Kolisis, F.N.; Menge, U. Lipase of Pseudomonas cepacia for biotechnological purpose, purification, crystallization and characterization. Biochim. Biophys. Acta. 1994, 1201, 55-60. [CrossRef] 
8. Albertsson, P.A. Chromatography and partition of cells and cell fragments. Nature 1956, 177, 771-774. [CrossRef]

9. Ko, M.J.; Park, H.J.; Hong, S.Y.; Yoo, Y.J. Continuous biodiesel production using in situ glycerol separation by membrane bioreactor system. Bioprocess Biosyst. Eng. 2012, 35, 65-75. [CrossRef]

10. Kinoshita, T.; Nii, S. Foam Separation of Metal Ions and the Potential 'Green' Alternative to Solvent Extraction. Solvent. Extr. Res. Dev. 2012, 19, 1-15. [CrossRef]

11. Malysa, K.; Krasowska, M.; Krzan, M. Influence of surface active substances on bubble motion and collision with various interfaces. Adv. Colloid Interface Sci. 2005, 114, 205-225. [CrossRef]

12. Wennerström, H.; Lindman, B.M. Physical chemistry of surfactant association. Phys. Rep. 1979, 52, 1-86. [CrossRef]

13. Burghoff, B. Foam fractionation applications. J. Biotechnol. 2012, 161, 126-137. [CrossRef] [PubMed]

14. Uppenberg, J.; Hansen, M.T.; Patkar, S.; Jones, T.A. The sequence, crystal structure determination and refinement of two crystal forms of lipase B from Candida antarctica. Structure 1994, 2, 293-308. [CrossRef]

15. Liu, W.; Zheng, H.J.; Wu, Z.L.; Wang, Y. Effects of $\mathrm{pH}$ profiles on nisin fermentation coupling with foam separation. Appl. Microbiol. Biot. 2010, 85, 1401-1407. [CrossRef] [PubMed]

16. Pilon, L.; Viskanta, R. Minimum superficial gas velocity for onset of foaming. Chem. Eng. Process. 2004, 43, 149-160. [CrossRef]

17. Li, X.L.; Zhang, W.; Chen, Y.T.; Xu, J. Optimization of a Foam Separation Process for Acid Fraction Gum from Flax Seeds by Response Surface Methodology. Sep. Sci. Technol. 2015, 50, 1906-1913. [CrossRef]

18. Stasiuk, E.N.B.; Schramm, L.L. The temperature dependence of the critical micelle concentrations of foam-forming surfactants. J. Colloid Interface Sci. 1996, 178, 324-333. [CrossRef]

19. Shao, W.Y.; Zhang, J.Y.; Lin, Y.; Cui, S.; Luo, S. The selection of a surfactant for freshwater microalgae harvesting and separation by the foam separation method. Bioproc. Biosyst. Eng. 2019, 42, 1721-1730. [CrossRef]

20. Alhseinat, E.; Amr, M.; Jumah, R.; Banat, F. Removal of MDEA foam creators using foam fractionation: Parametric study coupled with foam characterization. J. Nat. Gas. Sci. Eng. 2015, 26, 502-509. [CrossRef]

21. Stoscheck, C.M. Increased uniformity in the response of the Coomassie Blue G protein assay to different protein. Anal. Biochem. 1990, 184, 111. [CrossRef]

22. Pfeffer, J.; Richter, S.; Nieveler, J.; Hansen, C.; Rhlid, R.B.; Schmid, R.D.; Rusnak, M. High yield expression of Lipase A from Candida antarctica in the methylotrophic yeast Pichia pastoris and its purification and characterisation. Appl. Microbiol. Biotechnol. 2006, 72, 931-938. [CrossRef] [PubMed]

23. Boonyasuwat, S.; Chavadej, S.; Malakul, P.; Scamehorn, J.F. Surfactant recovery from water using a multistage foam fractionator: Part I-Effects of air flow rate, foam height, feed flow rate and number of stages. Sep. Sci. Technol. 2005, 40, 1835-1853. [CrossRef] 